\begin{tabular}{l|l} 
Potaice & e-ISSN: 2655-9404 p-ISSN: 2721-8376 \\
Vol. 5 No. 1, Februari 2022 & DOI: $10.20473 /$ ntr.v5i1.21882
\end{tabular}

Article history: Submitted 6 September 2021; Accepted 29 September 2021; Available online 24 February 2022.

\title{
Sistem Publikasi Pendaftaran Tanah (Kajian Sistem Publikasi Negatif Bertendensi Positif)
}

\author{
Agus Suhariono, Mochamad Kevin Romadhona, \\ Muhammad Indra Yanuardi, Muammar Zaid Nampira \\ agus.suhariono@gmail.com \\ Universitas Airlangga
}

\begin{abstract}
The purpose of this writing is to determine the effectiveness of the power of proof of title to land that has met the elements stipulated in Article 32 paragraph (2) of Government Regulation Number 24 of 1997 concerning Land Registration before the court. This writing method is a normative juridical type using the statutory approach, conceptual approach and case approach. From the results of the discussion, it is known that although the elements of the provisions stipulated in Article 32 paragraph (2) have been fulfilled late, it does not make the land title certificate have absolute, irrevocable power of proof. It is evident from a number of court decisions that they still cancel land title certificates even though they have fulfilled these elements.

Keywords: Certificate; Publication System; Multiple Proof.
\end{abstract}

\section{Abstrak}

Tujuan penulisan ini adalah untuk mengetahui efektifitas kekuatan pembuktian serfifkat hak atas tanah yang telah memenuhi unsur-unsur yang diatur dalam Pasal 32 ayat (2) Peraturan Pemerintah Nomor 24 Tahun 1997 tentang Pendaftaran Tanah dimuka pengadilan. Metode penulisan ini adalah penulisan bertipe yuridis normatif dengan menggunakan pendekatan peraturan perundang-undangan, pendekatan konseptual dan pendekatan kasus. Dari hasil pembahasan diketahui bahwa walaupun unsur-unsur ketentuan yang diatur dalam Pasal 32 ayat (2) tersebut telat terpenuhi tidak menjadikan sertifikat hak atas tanah memiliki kekuatan pembuktian mutlak yang tidak dapat dibatalkan. Terbukti dari beberapa putusan pengadilan tetap membatalkan sertifikat hak atas tanah walaupun telah memenuhi unsur-unsur tersebut.

Kata Kunci: Sertifikat; Sistem Publikasi; Alat Pembuktian Multak.

Copyright () 2022 Agus Suhariono, M. Kevin Romadhona, M. Indra Yanuardi, Muammar Zaid Nampira. Published in Notaire. Published by Universitas Airlangga, Magister Kenotariatan.

\section{Pendahuluan}

Pendaftaran tanah adalah sebuah kata yang berasal dari kata Cadastre atau suatu istilah dalam bahas inggris adalah Record (rekaman) yang artinya merujuk pada luas, nilai, dan kepemilikan (ha katas) terhadap suatu bidang tanah. ${ }^{1}$ Cadastre

\footnotetext{
${ }^{1}$ Tony, 'Penyelesaian Hukum Atas Penerbitan Sertipikat Hak Atas Tanah Yang Cacad Hukum Administratif Dikantor Pertanahan Kota Batam' (Universitas Internasional Batam 2015).
} 
adalah alat yang tepat untuk memberikan uraian dan identifikasi dari uraian tersebut dan juga sebagai continuous recording (rekaman berkesinamnbungan) dari ada ha katas tanah. ${ }^{2}$

Perkembangan peraturan pendafataran tanah dibagi kedalam 4 tahapan, yaitu: ${ }^{3}$

1. Masa Pra Kadaster;

2. Masa Kadaster Lama;

3. Masa Kadaster Baru;

4. Masa Kadaster Modern.

Sistem publikasi pendaftaran tanah telah diatur dalam Undang-undang No 5 Tahun 1960, yaitu tentaang Peraturan Dasar Pokok-pokok Agraria, lebih jelas diatur dalam Pasal 19 Ayat (1) yakni, menjamin kepastian hukum oleh pemerintah diadakan pendaftaran tanah diseluruh wilayah Republik Indonesia menurut ketentuan-ketentuan yang diatur dengan Peraturan Pemerintah. ${ }^{4}$ Implementasi dari Peraturan Dasar Pokok-pokok Agraria termuat dalam Peraturan Pemerintah Nomor 10 Tahun 1961 tentang pendaftaran tanah. ${ }^{5}$ PP No. 10 Tahun 1961 mengatur segala proses pendaftaran tanah di Indonesia dan akibat hukumnya dengan produk akhir adalah diterbitkan surat tanda bukti hak yang disebut dengan sertifikat tanah. ${ }^{6}$ Sebagaimana diatur dalam Pasal 1 Sub 20 PP No. 24 Tahun 1997 menyatakan bahwa sertifikat hak atas tanah adalah surat tanda bukti hak, sebagiamana dimaskud dalam Pasal 19 Ayat (2c) UUPA. ${ }^{7}$

Sistem publikasi pendaftaran tanah mempengaruhi kekuatan pembuktian Sertifikat Hak Atas Tanah. ${ }^{8}$ Sistem publikasi digunakan untuk menguji daya

${ }^{2}$ Urip Santoso, Hukum Agraria: Kajian Komprehensif (Kencana 2012).

${ }^{3}$ U. Indrayanto, 'Perubahan Pokok Dalam Peraturan Pendaftaran Tanah Menurut Pp Nomor 10 Tahun 1961 Dengan Pp Nomor 24 Tahun 1997’ (2006) 36 Jurnal Huklln1 dan Pembangunan.[290].

${ }^{4}$ Alvian B. Tumbal, 'Tinjauan Yuridis Terhadap Kedudukan Kepemilikan Sertifikat Hak Atas Tanah Dalam Sistem Pembuktian Perdata' (2018) 6 Lex Privatum.[38].

${ }^{5}$ A.P.Parlindungan, Pendaftaran Tanah Di Indonesia (Mandar Maju).

${ }^{6}$ Anggita Doramia Lumbanraja Fina Ayu Safitri, Lita Tyesta ALW., 'Akibat Hukum Penggunaan Sistem Publikasi Negatif Berunsur Positifdalam Pendaftaran Tanah Di Kota Semarang' (2020) 13 Notarius.[789].

${ }^{7}$ Klaudius Ilkam Hulu, 'Kekuatan Alat Bukti Sertifikat Hak Milik Atas Tanah Dalam Bukti Kepemilikan Hak' (2021) 1 Jurnal Panah Keadilan.[28].

${ }^{8}$ Desi Apriani Arifin Bur, 'Sertifikat Sebagai Alat Pembuktian Yang Kuat Dalam Hubungannya Dengan Sistem Publikasi Pendaftaran Tanah' (2017) 1 UIR Law Review.[127]. 
kekuatan pembuktian sertifikat, yaitu kuat atau tidak kuat dan mutlak atau tidak mutlak ${ }^{9}$ Sistem publikasi pendaftaran tanah dibagi kedalam dua macam system yaitu, sistem positif dan sistem negatif. ${ }^{10}$

1. Sistem publikasi Positif

Menggunakan sistem pendaftaran hak sehingga harus ada register atau buku tanah sebagai suatu penyimpanan dan penyajian data yuridis dan sertifikat sebagai surat tanda bukti hak; ${ }^{11}$

2. Sistem publikasi Negatif

Menyatakan bahwa negara tidak menjamin kebenaran data yang diberikan. Pendaftaran hak atas tanah tidaklah merupakan jaminan pada nama yang terdaftar dalam buku tanah. ${ }^{12}$ Dengan kata lain bahwa hak dari kepemilikan atas tanah yang telah terdaftar dalam buku tanah masih memungkinan untuk dibantah dengan catatan bantahan tersebut dapat dibuktikan dengan alat-alat bukti yang cukup kuat. $^{13}$

Sistem publikasi positif menurut Hermanses mengkategorikan kedalam dua jenis sistem yakni sistem Torrens dan sistem Grundbuch. ${ }^{14}$ Keunggulan sistem publikasi positif Torrens dibandingkan dengan sistem publikasi negatif adalah: ${ }^{15}$

1. Ketidapastian diganti dengan kepastian;

2. Biaya peralihan berkurang;

3. Lebih singkat dan jelas;

4. Persetujuan disederhanakan, agar dapat mudah mengurus secara personal;

5. Penipuan dihalangi.

Sistem publikasi negatif menurut Hutagalung memiliki kelebihan dalam hal: ${ }^{16}$

1. Pemegang hak kepemilikan sesungguhnya terlindungi dari pihak lain yang tidak berhak atas tanah;

\footnotetext{
${ }^{9}$ Fina Ayu Safitri, Lita Tyesta ALW. (n 6).

${ }^{10}$ Boedi Harsono, Hukum Agraria Indonesia: Sejarah Pembentukan Undang-Undang Pokok Agraria, Isi, Dan Pelaksanaannya (Djambatan 2008).

${ }^{11}$ ibid.

${ }^{12}$ Bachtiar Effendy, Pendaftaran Tanah Di Indonesia Dan Pelaksanaannya (Alumni 1993).

${ }^{13}$ Bachsan Mustafa, Hukum Agraria Dalam Perspektif (Remadja Karya 1985).

${ }^{14} \mathrm{R}$ Hermanses, Pendaftaran Tanah Di Indonesia (Direktorat Jenderal Agraria 1981).

${ }^{15}$ Bachtiar Effendy (n 12).

${ }^{16}$ Arie S. Hutagalung, Tebaran Pemikiran Seputar Masalah Hukum Tanah (LPHI 2005).
} 
20 | Agus Suhariono, dkk: Sistem Publikasi Pendaftaran...

2. Adanya penyelidikan riwayat tanah sebelum penerbitan sertifikat;

3. Tidak adanya batasan waktu bagi pemilik tanah untuk menuntut haknya yang telah disertifikatkan oleh pihak lain.

Sistem publikasi pendaftaran tanah yang di anut Indonesia bukanlah keduanya, artinya bukan sistem positif murni bukan pula sistem negatif murni. Akan tetapi sistem negatif menuju positif. ${ }^{17}$

Sebagaimana amanat Pasal 19 Undang-Undang Nomor 5 Tahun 1960 tentang Peraturan Dasar Pokok-Pokok Agraria (selanjutnya disebut UUPA) telah diatur bahwa Pemenerintah diwajibkan menyelenggarakan pendaftaran tanah demi memberikan kepastian dan perlindungan hukum bagi pemegang hak atas tanah atau pihak-pihak yang berkepentingan.

Sedasar amanat Pasal 19 UUPA tersebut, kemudian diundangkan Peraturan Pemerintah Nomor 24 Tahun 1997 tentang Pendaftaran Tanah, ${ }^{18}$ (selanjutnya disebut PP 24/1997) yang di dalam Pasal 32 nya diatur mengenai sistem publikasi yang dianut dalam pendaftaran tanah di Indonesia. ${ }^{19}$

Ketentuan Pasal 32 ayat (1) PP 24/1997, diatur bahwa Sertifikat Hak Atas Tanah sebagai hasil dari kegiatan pendaftaran tanah yang berisikan data fisik dan data yuridis merupakan alat bukti yang kuat namun bukan alat pembuktian yang mutlak ${ }^{20}$ karena masih dimungkinkan digugat oleh pihak lain yang merasa berkepentingan. Artinya data fisik dan data yuridis yang tercantum dalamSertifikat tersebut adalah benar sampai dengan dapat dibuktikan sebaliknya. Kelemahan dari sistem publikasi negatif yang diatur dalam Pasal 32 ayat (1) tersebut adalah negara tidak menjamin kebenaran data fisik dan data yuridis. ${ }^{21}$ Sistem ini untuk

\footnotetext{
${ }^{17}$ Fina Ayu Safitri, Lita Tyesta ALW. (n 6).

${ }^{18}$ Peraturan Pemerintah Republik Indonesia Nomor 24 Tahun 1997 Tentang Pendaftaran Tanah 1997.

19 Satriawan Nurtanto, 'Implementasi Pasal 32 Ayat 2 Pp No 24 Tahun 1997 Tentang Pendaftaran Tanah, Studi Putusan Pengadilan Nomor 179/Pdt/2018/Bdg' (2019) 14 Media Bina Ilmiah.[2701].

${ }^{20}$ Juosfiel Sadpri Pansariang, 'Proses Dan Syarat Untuk Memperoleh Hak Milik Atas Tanah Di Indonesia' (2014) 2 Lex Privatum.[28].

${ }^{21}$ Nur Oloan, 'Perlindungan Hukum Terhadap Pemegang Sertifikat Hak Atas Tanah' [2016] Jurnal Warta.[5].
} 
melindungi pemilik tanah yang sebenarnya yang selalu dapat menuntut haknya tetapi telah didaftarkan orang lain. Pada sistem ini pula peralihan hak atas tanah tidak ditentukan oleh pendaftaran peralihan hak yang dilakukan, melainkan ditentukan oleh sahnya perbuatan hukum yang dilakukan.

Selanjutnya pada Pasal 32 ayat (2) nya diatur bahwa dalam kondisi dan keadaan tertentu, kekuatan pembuktian Sertifikat Hak Atas Tanah yang semula masih dimungkin dibatalkan menjadi alat pembuktian yang tidak dapat dibatalkan (mutlak) demi memberikan asas kepastian hukum apabila terpenuhi unsur-unsur:22

a. Sertifikat diterbitkan secara sah;

b. Perolehan tanah dilakukan dengan itikad baik;

c. Telah menguasai tanah secara fisik;

d. Sertifikat (termasuk pendaftaran peralihan hak) telah diterbitkan lebih dari 5 (lima) tahun.

Dengan terpenuhinya unsur-unsur diatas, seolah-olah menjadikan Sertifikat Hak Atas Tanah (termasuk pendaftaran peralihan hak) sebagai alat pembuktian yang bersifat mutlak yang sudah tidak dimungkin dibatalkan lagi sehingga pihakpihak yang merasa memiliki hak sebelumnya menjadi kehilangan haknya untuk mengajukan penuntutan.

Yang menjadi permasalahan adalah apakah dengan terpenuhinya unsurunsur yang diatur Pasal 32 ayat (2) PP 24/1997 menjadikan sertifikat hak atas tanah berlaku mutlak dan tidak dapat dibatalkan sebagaimana sistem publikasi positif?.

\section{Metode Penulisan}

Penulisan ini bertipe yuridis normative yaitu mengacu pada konsep hukum sebagai kaidah dengan metodenya yang doctrinal-nomologik yang bertitik tolak pada kaidah ajaran yang mengkaidai perilaku ${ }^{23}$ dengan menggunakan pendekatan

\footnotetext{
${ }^{22}$ Sri Hajati, Buku Ajar Politik Hukum Pertanahan (Airlangga University Press 2017).

${ }^{23}$ Vidya Prahassacitta, 'Penelitian Hukum Normatif Dan Penelitian Hukum Yurudi' (Binus University Business Law, 2019).
} 
peraturan perundang-undangan yang mengikat, pendekatan konseptual dan pendekatan kasus.

\section{Rangkaian Kegiatan Pendaftaran Tanah}

Sebagaimana amanat Pasal 19 UUPA, Pemerintah diwajibkan untuk menyelenggarakan pendaftaran tanah. ${ }^{24}$ Pelaksanaan kegiatan pendaftaran tanah tersebut dilakukan oleh Kementerian Agraria dan Tata Ruang/Badan Pertanahan Nasional yang merupakan lembaga pemerintah yang mempunyai tugas di bidang pertanahan. ${ }^{25}$

Kegiatan pendaftaran tanah merupakan serangkaian kegiatan mulai dari pengumpulan data sampai dengan penyajian serta pemeliharaan data. ${ }^{26}$ Pendaftaran tanah tidak hanya mendaftarkan tanah secara fisik melainkan juga termasuk mendaftarkan hak atas untuk menentukan status hukum tanah. ${ }^{27}$ Jenis Pelaksanaan Pendaftaran Tanah meliputi: ${ }^{28}$

a. Pendaftaran tanah untuk pertama kali

Kegiatan pendataran yang dilakukan terhadap tanah yang belum pernah didaftarkan. ${ }^{29}$

Kegiatan ini dapat dilakukan melalui dua cara, yaitu ${ }^{30}$

1) Secara Sistematik ${ }^{31}$

Atas inisiatif pemerintah dan dibiayai oleh negara yang dilakukan secara serentak dalam wilayah atau bagian wilayah desa/kelurahan.

\footnotetext{
${ }^{24}$ 'Penjelasan Atas Peraturan Pemerintah Nomor 10 Tahun 1961 Tentang Pendaftaran Tanah' (JDIH Kemenkeu).

${ }^{25}$ Meita Djohan Oe, 'Tugas Dan Fungsi Badan Pertanahan Nasional Dalam Pendaftaran Tanah' (2015) 10 Pranata Hukum.[66].

${ }^{26}$ Urip Santoso, Pendaftaran Dan Peralihan Hak Atas Tanah, Cetakan Kedua (Kencana Prenada Media Group 2011).

27 Peraturan Pemerintah Republik Indonesia Nomor 24 Tahun 1997 Tentang Pendaftaran Tanah.

${ }^{28}$ ibid.

${ }^{29}$ ibid.

$30 \mathrm{ibid.}$

${ }^{31}$ Sovia Hasanah, 'Pendaftaran Tanah Secara Massal' (HukumOnline.com, 2017).
} 
2) Secara Sporadik ${ }^{32}$

Atas inisiatif dan dibiayai sendiri oleh pemilik tanah baik secara individual maupun secara bersama-sama (massal).

b. Pemeliharaan data

Kegiatan yang dilakukan untuk melakukan perubahan data fisik dan data yuridis. Kegiatan ini dibagi menjadi dua yaitu perubahan data fisik dan data yuridis tersebut. ${ }^{33}$

1) Perubahan Data Fisik ${ }^{34}$

Data fisik adalah keterangan mengenai letak, batas dan luas bidang tanah yang didaftarkan.

Kegiatan perubahan data fisik ini menyebabkan peta, surat ukur dan buku tanah berubah. Misal suatu bidang tanah yang sudah terdaftar (memiliki sertifikat) fisiknya seluas $1.000 \mathrm{~m} 2$, oleh pemegang haknya hendak di pecah menjadi dua bagian masing-masing seluas 500m2. Atau sebaliknya dua bidang tanah yang fisiknya berdampingan dan dimiliki oleh orang (subyek) yang sama hendak digabung.

2) Perubahan Data Yuridis ${ }^{35}$

Data yuridis adalah keterangan mengenai status hukum bidang tanah yang didaftarkan yang meliputi status hukum haknya (misal Hak Milik, Hak Guna Usaha dsb), status hukum pemegang hak dan pembebanannya antara lain hak tanggungan, blokir dan sita.

Kegiatan perubahan data yuridis ini menyebabkan status hukum hak (misal perubahan dari HGB mejadi Hak Milik), status hukum pemegang haknya (misal berubah baik karena mutasi adanya peralihan hak, karena pembebanan hak tanggunan, karena adanya blokir dan sita.

32 ibid.

${ }^{33}$ Akur Nurasa dan Dian Aries Mujiburohman, Pemeliharaan Data Pendaftaran Tanah (STPN Press 2020).

34 ibid. [83].

35 ibid. [84]. 
Rangkaian Pendaftaran Tanah menurut ketentuan Pasal 19 ayat (2) UUPA, meliputi: ${ }^{36}$

1. Pengukuran, perpetaan dan pembukuan tanah;

2. Pendaftaran hak-hak atas tanah dan peralihan hak tersebut;

3. Pemberian surat-surat tanda bukti hak, yang berlaku sebagai alat pembuktian yang kuat.

\section{Keputusan Tata Usaha Negara Pada Sertifikat Hak Atas Tanah}

Hasil akhir dari kegiatan pendaftaran tanah adalah diterbitkannya Sertifikat Hak Atas Tanah, yang diberikan kepada pihak yang berkepentingan sebagai bukti telah dilakukannya pendaftaran tanah, baik kegiatan pendaftaran tanah untuk pertama kali maupun kegiatan pendaftaran tanah dalam rangka pemeliharaan data.

Di tinjau dari hukum administrasi negara, Sertifikat Hak Atas Tanah merupakan dokumen yang dikeluarkan dan diterbitkan oleh Pemerintah (dalam hal ini BPN) yang merupakan pejabat tata usaha negara ${ }^{37}$ untuk dijadikan alat bukti. Jika ditinjau dari hukum perdata, merupakan alat bukti otentuk karena memenuhi syarat-syarat otentisitas sebagaimana diatur dalam Pasal 1868 Burgelijk Wetboek (BW), yaitu unsur-unsur: ${ }^{38}$

a. dibuat dalam bentuk yang ditentukan undang-undang (PP 24/1997 jo UUPA);

b. dibuat oleh pejabat yang berwenang (Kepala Kantor Pertanahan);

c. ditempat kedudukan pejabat (Kepala Kantor Pertanahan) tersebut berwenang sesuai wilayah hukum Kantor Pertanahan).

Dengan demikian dapat diartikan bahwa Sertifikat Hak Atas Tanah merupakan produk yang diterbitkan oleh pejabat tanah usaha, maka Sertifikat Hak Atas Tanah merupakan Keputusan Tata Usaha Negara (KTUN). Tanah

${ }^{36}$ Peraturan Pemerintah Republik Indonesia Nomor 24 Tahun 1997 Tentang Pendaftaran

${ }^{37}$ Pasal 14 ayat (1) Undang-Undang No. 4 Tahun 1996 tentang Hak Tanggungan Atas Tanah Beserta Benda-Benda Yang Berkaitan Dengan Tanah ("UU Hak Tanggungan”).

${ }^{38}$ Mudjiharto dan Ghansham Anand, 'Otentisitas Akta Perjanjian Kredit Dan Pembebanan Jaminan Yang Dibuat Tanpa Kehadiran Kreditor' (2017) 9 Al-Adl.[378]. 
Prosedur pendaftaran tanah didalamnya terdapat unsur keperdataannya, baik pada pendaftaran untuk pertama kali maupun pemeliharaan data. ${ }^{39}$ Aspek perolehan tanah dan peralihan hak, merupakan aspek keperdataan. Misal perolehan tanah melalui pelepasan hak yang kemudian dijadikan dasar permohonan hak, tentunya perbuatan hukum pelepasan hak tersebut merupakan perbuatan hukum perdata. Atau peralihan hak berdasarkan alat bukti dibawah tangan pada prosedur pengakuan hak pada pendaftaran tanah sistematik maupun sporadik. Atau juga peralihan hak karena jual beli, hibah, lelang dsb, pada tanah yang telah diterbitkan sertifikat, yang mana hal tersebut harus dibuktikan dengan akta pejabat yang berwenang.

Hal tersebut menjadikan sertifikat hak atas tanah bukan murni produk KTUN yang mana keberatan atas penerbitan KTUN menjadi wewenang peradilan tata usaha negara. ${ }^{40}$ Namun juga menjadi wewenang peradilan umum dan peradilan agama yang terkait dengan aspek keperdataan tersebut.

\section{Putusan-putusan Pengadilan Yang Membatalkan Sertifikat Hak Atas Tanah}

Sebagaimana disinggung diatas, Sertifikat Hak Atas Tanah bukanlah murni Keputusan Tata Usaha Negara (KTUN) akan tetapi didalamnya juga terdapat aspek keperdataan sehingga upaya hukum terhadap keberatan penerbitan Sertifikat Hak Atas Tanah bukan hanya menjadi wewenang peradilan tata usaha negara saja, akan tetapi juga menjadi wewenang peradilan umum dan peradilan agama.

Terdapat putusan-putusan pengadilan yang amar putusannya pada intinya membatalkan Sertifikat Hak Atas Tanah, baik yang diputus oleh peradilan tata usaha negara maupun oleh peradilan umum dan peradilan agama.

${ }^{39}$ Harris Yonatan Parmahan Sibuea, 'Arti Penting Pendaftaran Tanah Untuk Pertama Kali' (2011) 2 Negara Hukum.[287].

40 AA Gede Aditya Kusuma, I Wayan Parsa and Nengah Suharta, 'Kewenangan Badan Petanahan Nasional Terhadap Keputusan Pengadilan Tata Usaha Negara Yang Membatalkan Sertifikat Hak Atas Tanah’. 
26 | Agus Suhariono, dkk: Sistem Publikasi Pendaftaran...

a. Putusan peradilan tata usaha negara

Dijumpai pada kasus sengketa tata usaha terkait penerbitan sertifikat HGU yang letaknya tumpang tindih dengan sertifikat Hak Milik yang telah diterbitkan sebelumnya yang diputus oleh Pengadilan Tata Usaha Negara Pontianak Nomor36/G/2011/PTUN-PTK yang putusannya dikuatkan hingga ke tingkat kasasi yaitu berdasarkan putusan Mahkamah Agung RI. Nomor 550 K/TUN/2013, yang pada intinya membatalkan keputusan penerbitan HGU.

b. Putusan peradilan umum

Dijumpai pada kasus sengketa kepemilikan tanah terkait perbuatan hukumjual beli dan pendaftaran peralihan haknya yang diputus oleh Pengadilan Negeri Rantau Parapat Nomor 17/Pdt.G/2013/PN-RAP yang amar putusannya pada intinya menyatakan batal Akta Jual Beli yang dibuat dihadapan PPAT dan pendaftaran peralihan haknya.

c. Putusan peradilan agama

Dijumpai pada sengketa kepemilikan tanah yang orang-orangnya beragama islam terkait hibah tanah yang diputus oleh Pengadilan Agama Ambarawa Nomor 79/Pdt.G/2013/PA.Amb., yang putusan tersebut dikuatkan hingga tingkat kasasi berdasarkan Putusan Mahkamah Agung RI Nomor 170 K/ Ag/2016, yang pada intinya menyatakan batal penghibahan yang dibuktikan dengan Akta Hi bah yang dibuat dihadapan PPAT dan pendaftaran peralihan haknya.

Dari berbagai putusan peradilan tersebut menunjukkan bahwa Sertipikat Hak Atas Tanah (SHAT) yang diterbitkan oleh pejabat tata usaha (Kepala Kantor Pertanahan) bukanlah murni Keputusan Tata Usaha Negara (KTUN) namun terdapat aspek keperdataan. Sehingga keberatan atas penerbitan Sertifikat Hak Atas Tanah tersebut dapat dilakukan kepada peradilan sesuai kewenangan absolutnya.

Penulis mendapati bahwa SHAT digugat ke peradilan tata usaha negara bilamana terjadi sengketa mengenai data fisik (letak dan batas-batasnya) dan terkait dengan Surat Keputusan Pemberian Hak (SKPH). Sedangkan SHAT 
digugat ke peradilan umum atau peradilan usaha bilamana terkait dengan sengketa perbuatan hukum pemegang haknya (data yuridis).

\section{Jangka Waktu Pengajuan Tuntutan Pembatalan}

Dari ketiga jenis peradilan yang diurai diatas, hanya peradilan tata usaha yang mengatur mengenai jangka waktu pengajuan tuntutan. Sedang pada peradilan umum dan peradilan agama tidak dikenal mengenai daluarsa pengajuan tuntutan. Oleh karenanya pengajuan tuntutan pembatalan terhadap SHAT berusaha dibatasi oleh ketentuan Pasal 32 ayat (2) PP 24/1997, yaitu bilamana SHAT telah diterbitkan 5 (lima) tahun maka pihak lain yang merasa hak tidak dapat lagi menuntut pelaksanaan hak tersebut.

Penulis berpendapat bahwa ratio penetapan jangka waktu 5 (lima) tahun tersebut adalah apabila dalam waktu 5 (lima) tahun tidak menguasai tanah maka dapat dianggap sebagai menelantarkan tanah sehingga kehilangan haknya.

Lewatnya waktu (daluarsa) untuk menuntut tersebut dikenal dalam hukum adat yang merupakan sumber utama diundangkannya UUPA. Dalam hukum adat jika seseorang sekian lama membiarkan tanahanya tidak dikerjakan, kemudian tanah tersebut dikerjakan orang lain yang memperolehnya dengan itikad baik, maka hilangla haknya untuk menuntut. ${ }^{41}$ Hal tersebut dikenal sebagai lembaga rechtverwerking.

Ternyata keberadaan lembaga rechtverwerking tidak menjadi pertimbangan bagi hakim dalam memeriksa dan menyidangkan sengketa kepemilikan tanah. Hakim lebih tunduk dan berpedoman kepada hukum acara perdata (HIR dan Rbg) bagi peradilan umum begitupun bagi peradilan agama yang juga memberlakukan hukum acara perdata kecuali yang secara khusus diatur dalam UU Peradilan Agama.

HIR dan Rbg mengatur mengenai hak menggugat warga negara, sedangkan Pasal 32 ayat (2) membatasi seseorang untuk melakukan gugatan. Hal tersebut tentunya menimbulkan konflik norma. Jika berdasarkan asas hukum lex superior

${ }^{41}$ Maria Sumarjono, Kebijakan Pertanahan Antara Regulasi Dan Implementasi (Buku Kompas 2006). 
28 Agus Suhariono, dkk: Sistem Publikasi Pendaftaran...

derogat lex inferior (hukum yang derajatnya lebih tinggi mengalahkan hukum yang derajatnya lebih rendah).

Pengaturan Pasal 32 ayat (2) PP 24/1997 memiliki derajat yang lebih rendah daripada HIR/Rbg yang merupakan peraturan setingkat undang-undang. Dengan demikian tidaklah salah apabila hakim mengabaikan lembaga rechtverwerking yang dalam hukum positif diatur oleh Pasal 32 ayat (2) PP 24/1997.

Putusan pengadilan yang membatalkan SHAT walaupun telah memenuhi unsur-unsur yang diatur dalam Pasal 32 ayat (2) PP 24/1997 menunjukkan bahwa pengaturan Pasal 32 ayat (2) tersebut tidak efektif.

\section{Kesimpulan}

Pengaturan Pasal 32 ayat (2) Peraturan Pemerintah Nomor 24 Tahun 1997 tentang Pendaftaran Tanah memiliki tujuan agar kepastian hukum dalam pendaftaran tanah yang perlidungan hukum bagi pemegang hak atas tanah dapat tercapai. Akan tetapi ternyata hakim pada peradilan umum dan peradilan agama lebih berpedoman pada norma yang diatur dalam hukum acara perdata dalam menerima gugatan pencari keadilan daripada memperhatikan hilangnya hak untuk menuntut (daluarsa) yang diatur Pasal 32 ayat (2) PP 24/1997.

Pengesampingan ketentuan Pasal 32 ayat (2) tersebut menjadikan ketentuan tersebut tidak mengikat dalam arti tidak memiliki daya berlaku, sehingga Pasal 32 ayat (2) tidak efektif dalam memberikan pengaturan bahwa sistem publikasi pendaftaran tanah adalah negatif yang bertendensi positif.

\section{Daftar Bacaan}

\section{Buku}

A.P.Parlindungan, Pendaftaran Tanah Di Indonesia (Mandar Maju).

Akur Nurasa dan Dian Aries Mujiburohman, Pemeliharaan Data Pendaftaran Tanah (STPN Press 2020).

Arie S. Hutagalung, Tebaran Pemikiran Seputar Masalah Hukum Tanah (LPHI 2005). 
Bachsan Mustafa, Hukum Agraria Dalam Perspektif (Remadja Karya 1985).

Bachtiar Effendy, Pendaftaran Tanah Di Indonesia Dan Pelaksanaannya (Alumni 1993).

Harsono B, Hukum Agraria Indonesia : Sejarah Pembentukan Undang-Undang Pokok Agraria, Isi, Dan Pelaksanaannya (Djambatan 2008).

Kusuma AAGA, Parsa IW and Suharta N, 'Kewenangan Badan Petanahan Nasional Terhadap Keputusan Pengadilan Tata Usaha Negara Yang Membatalkan Sertifikat Hak Atas Tanah'.

Maria Sumarjono, Kebijakan Pertanahan Antara Regulasi Dan Implementasi (Buku Kompas 2006).

R Hermanses, Pendaftaran Tanah Di Indonesia (Direktorat Jenderal Agraria 1981).

Santoso U, Hukum Agraria: Kajian Komprehensif (Kencana 2012).

Sri Hajati D, Buku Ajar Politik Hukum Pertanahan (Airlangga University Press 2017).

Tony, ‘Penyelesaian Hukum Atas Penerbitan Sertipikat Hak Atas Tanah Yang Cacad Hukum Administratif Dikantor Pertanahan Kota Batam' (Universitas Internasional Batam 2015).

Urip Santoso, Pendaftaran Dan Peralihan Hak Atas Tanah, Cetakan Kedua (Kencana Prenada Media Group 2011).

Vidya Prahassacitta, 'Penelitian Hukum Normatif Dan Penelitian Hukum Yurudi' (Binus University Business Law, 2019).

\section{Jurnal}

Alvian B. Tumbal, 'Tinjauan Yuridis Terhadap Kedudukan Kepemilikan Sertifikat Hak Atas Tanah Dalam Sistem Pembuktian Perdata' (2018) 6 Lex Privatum.

Arifin Bur DA, 'SertifikatSebagai Alat Pembuktian Yang Kuat Dalam Hubungannya Dengan Sistem Publikasi Pendaftaran Tanah' (2017) 1 UIR Law Review.

Fina Ayu Safitri, Lita Tyesta ALW. ADL, 'Akibat Hukum Penggunaan Sistem Publikasi Negatif Berunsur Positifdalam Pendaftaran Tanah Di Kota Semarang' (2020) 13 Notarius.

Harris Yonatan Parmahan Sibuea, 'Arti Penting Pendaftaran Tanah Untuk Pertama Kali’ (2011) 2 Negara Hukum. 
Juosfiel Sadpri Pansariang, 'Proses Dan Syarat Untuk Memperoleh Hak Milik Atas Tanah Di Indonesia' (2014) 2 Lex Privatum.

Klaudius Ilkam Hulu, 'Kekuatan Alat Bukti Sertifikat Hak Milik Atas Tanah Dalam Bukti Kepemilikan Hak' (2021) 1 Jurnal Panah Keadilan.

Meita Djohan Oe, 'Tugas Dan Fungsi Badan Pertanahan Nasional Dalam Pendaftaran Tanah' (2015) 10 Pranata Hukum.

Mudjiharto dan Ghansham Anand, 'Otentisitas Akta Perjanjian Kredit Dan Pembebanan Jaminan Yang Dibuat Tanpa Kehadiran Kreditor' (2017) 9 AlAdl.

Nur Oloan, 'Perlindungan Hukum Terhadap Pemegang Sertifikat Hak Atas Tanah' [2016] Jurnal Warta.

Satriawan Nurtanto, 'Implementasi Pasal 32 Ayat 2 Pp No 24 Tahun 1997 Tentang Pendaftaran Tanah, Studi Putusan Pengadilan Nomor 179/Pdt/2018/Bdg' (2019) 14 Media Bina Ilmiah.

U. Indrayanto, 'Perubahan Pokok Dalam Peraturan Pendaftaran Tanah Menurut Pp Nomor 10 Tahun 1961 Dengan Pp Nomor 24 Tahun 1997’ (2006) 36 Jurnal Hukum dan Pembangunan.

\section{Laman}

Sovia Hasanah, 'Pendaftaran Tanah Secara Massal' (HukumOnline.com, 2017).

\section{Perundang-undangan}

Penjelasan Atas Peraturan Pemerintah Nomor 10 Tahun 1961 Tentang Pendaftaran Tanah' (JDIH Kemenkeu).

Pasal 14 ayat (1) Undang-Undang No. 4 Tahun 1996 tentang Hak Tanggungan Atas Tanah Beserta Benda-Benda Yang Berkaitan Dengan Tanah (“UU Hak Tanggungan").

Peraturan Pemerintah Republik Indonesia Nomor 24 Tahun 1997 Tentang Pendaftaran Tanah 1997.

How to cite: Agus Suhariono, Mochamad Kevin Romadhona, Muhammad Indra Yanuardi, Muammar Zaid Nampira, 'Sistem Publikasi Pendaftaran Tanah (Kajian Sistem Publikasi Negatif Bertendensi Positif)' (2022) Vol. 5 No. 1 Notaire. 